\title{
Adlay (Coix lacryma-jobi L.) and Napier grass (Pennisetum purpureum Schum.) intercropping and fertilization schemes as climate smart strategy for food and feed production
}

\author{
Nello D. Gorne ${ }^{1 *}$ and Agripina R. Aradilla ${ }^{2}$
}

\begin{abstract}
Submitted: 13 February 2019 | Accepted: 24 March 2020

Adlay is considered an alternate staple food crop in the Philippines while napier is a versatile multipurpose fodder crop. Effective intercropping and fertilization strategies for the production of these crops could help address the problems on food and feed supply. The objectives of the study were to 1) evaluate the growth and yield of adlay with napier at various fertilization scheme; 2) determine the appropriate intercropping and fertilization schemes for maximum adlay production; 3 ) appraise the efficiency of intercropping scheme; and 4) assess the profitability of intercropping adlay with napier at various fertilization scheme. The study was laid out in split-plot with three intercropping scheme $\left(\mathrm{C}_{1}=\right.$ Monocrop adlay, $C_{2}=$ Adlay with napier at 1:1 row ratio, and $C_{3}=$ Adlay with napier at 2:1 row ratio) and five fertilization schemes $\left(F_{0}=\right.$ Unfertilized, $F_{1}=120 \mathrm{~kg} \mathrm{ha}^{-1} \mathrm{~N}$ inorganic fertilizer, $F_{2}=60 \mathrm{~kg} \mathrm{ha}^{-1} \mathrm{~N}$ inorganic fertilizer $+1 \mathrm{t} \mathrm{ha}^{-1}$ chicken dung, $F_{3}=30 \mathrm{~kg} \mathrm{ha}^{-1} \mathrm{~N}$ inorganic fertilizer $+1.5 t$ ha $^{-1}$ chicken dung, and $F_{4}=2 t a^{-1}$ chicken dung). Fertilization scheme significantly affected the days to flowering and maturity, vegetative tillers, plant height, number of productive and unproductive tillers, panicle length, herbage and grain yields of adlay and also the tiller and herbage yield of napier as well as the land equivalent and area time equivalent ratios. Fertilization with pure inorganic fertilizer or with combinations of chicken dung had ROI of 1.31 to 1.44 per peso invested.
\end{abstract}

Keywords: alternate staple, chicken dung, land equivalent ratio, versatile crop

\section{INTRODUCTION}

Sustainable crop production is a must in order for humankind to survive. However, such a vision is under threat by a number of factors that affect all the flora

'Department of Agronomy, College of Agriculture and Food Science, Baybay City, Leyte, Philippines

${ }^{2}$ Department of Agronomy and Plant Breeding, CMU, Musuan, Maramag, Bukidnon, Philippines

\footnotetext{
*Corresponding Author. Address: Department of Agronomy, College of Agriculture and Food Science, Baybay City, Leyte, Philippines; Email: nello.gorne@vsu.edu.ph

DOI: $10.32945 /$ atr4215.2020
} 
and fauna, especially in our country. Climate change, degradation of farmlands and pests are just a few of the problems affecting crop production. There is a need to come up with strategies in order to feed the exponentially growing population not solely dependent upon the supply of staple crops such as rice and corn.

Right now, the observed impact of global warming such as flooding, drought, rising temperature, heat waves, and extreme weather events have deleterious effects on crops and livestock. Zhao et al (2017) reported that each degree-Celsius increase in global mean temperature would reduce global yields of rice by $3.2 \%$. Thus, the vulnerable rice farming communities in the country and other developing countries, are most at risk. The introduction of a climate-smart crop as an alternate crop among rice farmers is therefore indispensable.

Adlay (Coix lacryma-jobi L.) is one of the crops that can possibly augment the food and feed supply as it can withstand heavy rains and long dry spell (Loeffler 2012). It is also called Job's tears because of its characteristically teardrop-shaped grains. A distant relative of maize, Adlay is utilized as food and consumed as a cereal or ground into flour and used as an ingredient for baking, herbal teas, medicines and soup. The grains can also be fermented and made into beer and other beverages (Health benefits times.com 2016).

Adlay differs from rice as it can tolerate poor soil condition, grows well in sloping areas and it is resilient to pests and diseases. It produces a large amount of biomass that can be used as mulch to mitigate soil erosion on slopes, hence, it is a suitable for sustainable agriculture. Mercado et al (2016) reported that the roots of adlai can grow up to $3 \mathrm{~m}$ into the subsoil which enables it to withstand dry spells.

Increasing farm productivity per unit area per unit time needs to be a part in the goal of sustaining the food and feed requirements of humankind, moreover arable lands have continually been decreasing due to conversion into non-agricultural uses as well as soil degradation. Intercropping is one of these measures to maximize the utilization of farmlands. It offers farmers the opportunity to engage in nature's principle of diversity on their farms.

Farm productivity can be bolstered by using napier grass (elephant grass) (Pennisetum purpureum Schum.) as intercrop. According to Cook et al (2005), it is a high yielding fodder crop with good palatability, and high nutrient content especially when leaves are young, dark green and less than $1 \mathrm{~m}$ tall. It is easy to establish and is persistent, drought tolerant, suitable for cutting and very good for silage making. According to Kafle and Balla (2008), broom grass and napier are most effective in reinforcing the soil by providing a network of strong roots that increase the soil's resistance to shear. Lemus and Lal (2005) included napier in the list of bioenergy crops which can sequester carbon and offset fossil fuel. Hybrid napier sequestered higher amounts of carbon when compared with hedge lucerne, fodder cowpea and fodder maize (Sivakumar et al 2014).

The nutrient contents of farmlands continuously decline as a consequence of crop removal, leaching, volatilization and soil erosion. It is then important to supply the nutrient needs of the crops for better growth and development. However, the kind, rate, method \& timing of fertilizer application have to be considered for sustained production. The use of organic fertilizer is a better choice over the inorganic fertilizer as it does not degrade soil quality. Organic fertilizer increases soil OM, improves soil structure and soil moisture holding capacity. Its use also mitigates climate change as it reduces $\mathrm{CO}_{2}$ emission into the atmosphere (Lemus \& Lal 2005). 
Chicken dung is an organic fertilizer which has the potential in sustaining the growth and development of crops. In fact, it is an effective fertilizer for the production of napier-bajra hybrid grass based on the findings of Bandeswaran et al (2013). Poultry manure was found efficient to increase carbon and nitrogen contents in soils compared to rice straw and cow dung (Rahman 2014).

This study was conducted to 1) evaluate the growth and yield of adlay with napier at various fertilization scheme, 2) determine the appropriate intercropping and fertilization schemes for optimum adlay production, 3) appraise the efficiency of intercropping scheme, and 4) assess the profitability of intercropping adlay with napier at various fertilization scheme.

\section{MATERIALS AND METHODS}

\section{Land Preparation, Soil Sampling and Analysis}

An experimental area of $2,500 \mathrm{~m}^{2}$ at the Visayas State University was plowed and harrowed twice after which furrows were made $100 \mathrm{~cm}$ apart. A composite soil sample was collected, air dried, pulverized, sieved and analyzed for soil $\mathrm{pH}$ (potentiometer method at 1:2.5 soil-water ratio), \% organic matter (Walkley and Black method), total $\mathrm{N}$ (Kjeldhal method), available $\mathrm{P}$ (Bray No. 2) and exchangeable $\mathrm{K}\left(1 \mathrm{~N} \mathrm{NH} \mathrm{NH}_{4} \mathrm{OAc}\right)$ contents at the Central Analytical Services Laboratory, PhilRootcrops, Visayas State University, Baybay City, Leyte, Philippines. The result of the soil analysis was the basis for the determination of the recommended rate of fertilizer application for adlay.

Final soil sampling was done right after harvesting by collecting samples from each treatment plot. The samples were composited per treatment plot, mixed thoroughly, processed, and then analyzed for the same soil parameters previously mentioned.

\section{Experimental Design and Treatments}

The experimental area was laid out in a split-plot arranged in RCBD with three main plots and five subplots replicated four times. The treatments were intercropping scheme $\left(\mathrm{C}_{1}=\right.$ Monocrop Adlay, $\mathrm{C}_{2}=$ Adlay intercropped with Napier at 1:1 row ratio and $\mathrm{C}_{3}=$ Adlay intercropped with $\mathrm{Napier}$ at 2:1 row ratio) and fertilization scheme $\left(F_{0}=\right.$ Unfertilized, $F_{1}=120 \mathrm{~kg} \mathrm{ha}^{-1} \mathrm{~N}, \mathrm{~F}_{2}=60 \mathrm{~kg} \mathrm{ha}^{-1} \mathrm{~N}+1 \mathrm{t} \mathrm{ha} \mathrm{a}^{-1}$ chicken dung, $F_{3}=30 \mathrm{~kg} \mathrm{ha}^{-1} \mathrm{~N}+1.5 \mathrm{t} \mathrm{ha}^{-1}$ chicken dung $\& \mathrm{~F}_{4}=2 \mathrm{tha}^{-1}$ chicken dung).

\section{Establishment of Treatment Plots}

The treatment plots designated for the intercropping of adlay with napier at 1:1 and 2:1 ratios were sown first with the incubated adlay seeds. The distance of planting was $100 \mathrm{~cm}$ between rows and $50 \mathrm{~cm}$ between hills with 5 seeds hill ${ }^{-1}$ which were thoroughly covered with soil. After 30 days, the napier canes were planted vertically with one node buried in the soil in between rows of adlay at $50 \mathrm{~cm}$ between hills for the 1:1 ratio treatment. For the 2:1 ratio treatment, one row of napier spaced $50 \mathrm{~cm}$ between hills for every two rows of adlay were planted vertically with one node buried in the soil. 
Adlay (Coix lacryma-jobi L.) and Napier grass intercropping \& fertilization

\section{Fertilizer Preparation and Application}

The different levels of chicken dung treatments were prepared and applied before sowing the adlay seeds. The $F_{2}, F_{3}$ and $F_{4}$ treatment plots with $24 \mathrm{~m}^{2}$ area each were applied with $2.4 \mathrm{~kg} \mathrm{plot}^{-1}, 3.6 \mathrm{~kg} \mathrm{plot}^{-1}$ and $4.8 \mathrm{~kg} \mathrm{plot}^{-1}$, respectively, by spreading evenly in the furrows. On the other hand, the $F_{1}, F_{2}$ and $F_{3}$ treatment plots with the same area of the previous plots were applied with $156.5 \mathrm{~g} \mathrm{plot}^{-1}, 78.25 \mathrm{~g} \mathrm{plot}^{-1}$ and $39.125 \mathrm{~g} \mathrm{plot}^{-1}$, respectively, in the furrows at planting while the remaining amount of $469.5 \mathrm{~g} \mathrm{plot}^{-1}, 234.75 \mathrm{~g} \mathrm{plot}^{-1}$ and $117.375 \mathrm{~g} \mathrm{plot}^{-1}$, respectively, were applied 30 days after planting using urea (46-0-0). The aforesaid fertilizer was covered with soil to avoid direct contact with the planting material and reduce nutrient losses.

Both the napier monocrop and intercrop treatments were not fertilized with the aforementioned organic and inorganic fertilizer materials.

\section{Cultural Management Practices for Adlay}

Prior to sowing, the adlay seeds (cv. Dwarf) were soaked for eight hours. After which, incubation was done for six hours by covering the seeds with a dried cloth.

Thinning was done one month after sowing by carefully removing the excess plants leaving only two healthy seedlings hill ${ }^{-1}$.

\section{Cultural Management Practices for Napier Grass}

Cuttings of napier (cv. Super Napier) with two nodes were prepared and placed in a cool shady place a day prior to planting. They were planted in between rows of adlay one month after adlay was planted. Hills with no observable live shoots emerging from the planted canes were replanted immediately.

\section{Pest Control}

Weeding was performed after thinning all treatment plots. Removal of regrowth and late emerging weeds was done manually until canopy closure.

Rat infestation was controlled by mixing $300 \mathrm{~g}$ baits with $10 \mathrm{~g}$ zinc phosphide until infestation subsided. Likewise, leafhopper infestation was controlled by spraying with Cypermethrin insecticide at $2 \mathrm{tbsp}$ per $16 \mathrm{~L}$ of water twice a week until infestation subsided.

\section{Harvesting}

Harvesting of adlay was done when $80 \%$ of the grains have turned brown by cutting the stover using a sharp sickle leaving three nodes above the ground. The harvested panicles were threshed and dried until $14 \%$ moisture content was attained. Harvesting of napier was done 60 days after planting and 45 days thereafter by cutting the tillers leaving one node from the ground using a sharp sickle. 


\section{Data Gathered}

The adlay agronomic characteristics gathered were days to emergence, flowering and maturity; number of vegetative tillers and plant height $(\mathrm{cm})$ while the yield and yield components were number of productive and non-productive tillers per hill, panicle length $(\mathrm{cm})$, number and percent filled grains per panicle, number and percent unfilled grains per panicle, moisture content of grains, weight of $1000 \mathrm{~g}$ seeds, herbage yield $\left(\mathrm{t} \mathrm{ha}^{-1}\right)$ and grain yield $\left(\mathrm{tha}^{-1}\right)$.

Number of tillers per hill and herbage yield $\left(t \mathrm{ha}^{-1}\right)$ were gathered for napier. Intercropping efficiency measures such as land equivalent ratio (LER) and area time equivalent ratio (ATER) as well as cost and return analysis were also determined.

\section{Statistical Analysis}

This was done through the analysis of variance of split-plot in Randomized Complete Block Design (RCBD) using STAR and SAS softwares. Significant differences among treatment means were compared using Tukey's Honestly Significant Difference (HSD) test.

\section{RESULTS AND DISCUSSION}

\section{Soil Analysis}

Results of initial soil analysis revealed that the study area had a pH of $6.47,0.52 \%$ organic matter, $0.02 \%$ total nitrogen, $82.04 \mathrm{mg} \mathrm{kg}^{-1}$ available phosphorus and $310 \mathrm{mg}$ $\mathrm{kg}^{-1}$ exchangeable potassium (Table 1 ). These indicate that the soil was slightly acidic with very low organic matter and nitrogen contents but with very high amounts of available phosphorus and potassium based on the soil chemical data interpretation of Landon (1991).

Final soil analysis showed a decrease in soil pH and available phosphorus and an increase in organic matter, organic carbon and total nitrogen contents in all treatment plots. The exchangeable potassium also increased in all treatment plots after harvest, except in plots planted with adlay intercropped with napier at 1:1 row ratio. The decrease in available phosphorus implies that its uptake by adlay and napier was greater than the inherent amount in the soil. The findings showed the potential of adlay for carbon sequestration as its herbage is not easily decomposed. Greater root exudates and more crop residues in response to mineral $\mathrm{N}$ fertilizer application were the dominant reasons why $\mathrm{N}$ fertilizer application improved the soil organic carbon (Christopher and Lal 2007). 
Adlay (Coix lacryma-jobi L.) and Napier grass intercropping \& fertilization

Table 1. Soil analysis of the experimental area before and after the conduct of the study

\begin{tabular}{|c|c|c|c|c|c|c|}
\hline Treatment & $\begin{array}{c}\mathrm{pH} \\
(1: 2.5)\end{array}$ & $\begin{array}{l}\text { SOM } \\
(\%)\end{array}$ & $\begin{array}{l}\text { SOC } \\
(\%)\end{array}$ & $\begin{array}{c}\text { Total N } \\
(\%)\end{array}$ & $\begin{array}{l}\text { Avail. P } \\
\left(\mathrm{mg} \mathrm{kg}^{-1}\right)\end{array}$ & $\begin{array}{l}\text { Exch. K } \\
\left(\mathrm{mg} \mathrm{kg}^{-1}\right)\end{array}$ \\
\hline Initial & 6.47 & 0.592 & 0.30 & 0.017 & 82.040 & 310.00 \\
\hline \multicolumn{7}{|l|}{ Intercropping Scheme } \\
\hline $\mathrm{C}_{1}=$ Monocrop Adlay & 6.24 & 1.16 & 0.58 & 0.10 & 10.80 & 365.43 \\
\hline $\begin{array}{c}\mathrm{C}_{2}=\text { Adlay and Napier } \\
\text { at } 1: 1 \text { ratio }\end{array}$ & 6.26 & 1.19 & 0.60 & 0.10 & 10.64 & 307.88 \\
\hline $\begin{array}{c}\mathrm{C}_{3}=\text { Adlay and Napier } \\
\text { at 2:1 ratio }\end{array}$ & 6.23 & 1.17 & 0.59 & 0.10 & 11.94 & 354.61 \\
\hline \multicolumn{7}{|l|}{ Fertilization Scheme } \\
\hline $\mathrm{F}_{0}=$ Unfertilized & 6.16 & 1.15 & 0.58 & 0.11 & 10.77 & 333.52 \\
\hline $\mathrm{F}_{1}=120 \mathrm{~kg} \mathrm{~N} \mathrm{ha}^{-1}$ & 6.26 & 1.19 & 0.59 & 0.09 & 10.93 & 339.19 \\
\hline $\begin{aligned} \mathrm{F}_{2}= & 60 \mathrm{~kg} \mathrm{~N} \mathrm{ha}^{-1}+1 \mathrm{t} \\
& \text { ha }^{-1} \text { chicken dung }\end{aligned}$ & 6.27 & 1.18 & 0.59 & 0.10 & 11.19 & 353.08 \\
\hline $\begin{array}{r}F_{3}=30 \mathrm{~kg} \mathrm{~N} \mathrm{ha}^{-1}+1.5 \mathrm{t} \\
\text { ha }^{-1} \text { chicken dung }\end{array}$ & 6.27 & 1.17 & 0.59 & 0.10 & 11.13 & 341.33 \\
\hline $\begin{array}{c}\mathrm{F}_{4}=2 \mathrm{t} \mathrm{ha}^{-1} \text { chicken } \\
\text { dung }\end{array}$ & 6.27 & 1.20 & 0.60 & 0.11 & 11.60 & 346.11 \\
\hline Mono-napier & 6.21 & 1.25 & 0.63 & 0.09 & 9.13 & 316.24 \\
\hline
\end{tabular}

\section{Agronomic Characteristics of Adlay}

Results revealed that the different intercropping scheme did not significantly influence the emergence of seedlings, flowering, maturity, vegetative tillers and height of adlay (Table 2). This implies that the genetic makeup or the environmental conditions had far more influence on the aforementioned parameters than the napier intercrop. Coles (2013) noted that adlay seeds germinated in 5 to 7 days after sowing under favorable conditions. However, Luceño (2017) observed that adlay germinated in 13 to 17 days after sowing during dry season planting and flowered at 198 days after sowing. Mostales and Aradilla (2016) observed that Dwarf adlay flowered at 102 days after sowing.

The fertilization scheme did not significantly influence the emergence of seedlings but significantly affected the flowering and maturity of adlay. The plants applied with $120 \mathrm{~kg} \mathrm{ha}^{-1} \mathrm{~N}$ were the earliest to flower and mature, followed by those applied with $60 \mathrm{~kg} \mathrm{ha}^{-1} \mathrm{~N}+1 \mathrm{tha}^{-1}$ of chicken dung and $30 \mathrm{~kg} \mathrm{ha}^{-1} \mathrm{~N}+1.5 \mathrm{tha}^{-1}$ of chicken dung. The plants applied with $2 \mathrm{t} \mathrm{ha} \mathrm{a}^{-1}$ chicken dung were the latest to flower and mature among fertilizer-treated plants. However, unfertilized adlay flowered and matured the latest. The results imply that high $\mathrm{N}$ rates hastened the flowering which conforms to the findings of Torred (2017). However, Salvador Sr (2016) and Torred (2017) found no significant effect of fertilization on the maturity of adlay. 
Gorne \& Aradilla

Table 2. Days to emergence, flowering and maturity, vegetative tillers per hill and plant height of adlay as affected by intercropping and fertilization schemes

\begin{tabular}{|c|c|c|c|c|c|}
\hline \multirow[b]{2}{*}{ Treatments } & \multicolumn{3}{|c|}{ Days to } & \multirow{2}{*}{$\begin{array}{c}\text { Vegetative } \\
\text { Tillers } \\
\text { Hill- }^{-1}\end{array}$} & \multirow{2}{*}{$\begin{array}{c}\text { Plant } \\
\text { Height } \\
(\mathrm{cm})\end{array}$} \\
\hline & Emergence & Flowering & Maturity & & \\
\hline \multicolumn{6}{|l|}{ Intercropping Scheme } \\
\hline $\mathrm{C}_{1}=$ Monocrop Adlay & 10.3 & 115.6 & 181.1 & 12.2 & 232.2 \\
\hline $\begin{array}{c}\mathrm{C}_{2}=\text { Adlay and Napier } \\
\text { at } 1: 1 \text { ratio }\end{array}$ & 10.4 & 114.6 & 181.5 & 11.8 & 221.8 \\
\hline $\begin{array}{c}\mathrm{C}_{3}=\text { Adlay and Napier } \\
\text { at 2:1 ratio }\end{array}$ & 10.5 & 115.5 & 181.6 & 11.8 & 222.8 \\
\hline F-test & ns & ns & ns & ns & ns \\
\hline $\mathrm{CV}_{\mathrm{a}}(\%)$ & 7.21 & 2.98 & 1.49 & 7.25 & 7.92 \\
\hline \multicolumn{6}{|l|}{ Fertilization Scheme } \\
\hline $\mathrm{F}_{0}=$ Unfertilized & 10.1 & $123.8^{a}$ & $188.1^{\mathrm{a}}$ & $8.3^{c}$ & $208.8^{b}$ \\
\hline $\mathrm{F}_{1}=120 \mathrm{~kg} \mathrm{ha}^{-1} \mathrm{~N}$ & 10.7 & $108.8^{d}$ & $176.3^{c}$ & $13.5^{\mathrm{a}}$ & $240.8^{a}$ \\
\hline $\begin{aligned} \mathrm{F}_{2}= & 60 \mathrm{~kg} \mathrm{ha} \mathrm{a}^{-1} \mathrm{~N}+1 \mathrm{t} \mathrm{ha} \mathrm{-}^{-1} \\
& \text { chicken dung }\end{aligned}$ & 10.1 & $111.3^{\mathrm{cd}}$ & $177.2^{\mathrm{bc}}$ & $13.5^{\mathrm{a}}$ & $236.9^{a}$ \\
\hline $\begin{aligned} \mathrm{F}_{3}= & 30 \mathrm{~kg} \mathrm{ha}{ }^{-1} \mathrm{~N}+1.5 \mathrm{t} \mathrm{ha} \mathrm{a}^{-1} \\
& \text { chicken dung }\end{aligned}$ & 10.8 & $113.7^{c}$ & $180.3^{b}$ & $14.0^{\mathrm{a}}$ & $230.2^{a}$ \\
\hline $\mathrm{F}_{4}=2 \mathrm{t} \mathrm{ha} \mathrm{a}^{-1}$ chicken dung & 10.3 & $118.5^{b}$ & $185.1^{\mathrm{a}}$ & $10.4^{b}$ & $211.4^{b}$ \\
\hline F-test & ns & $\star \star$ & $\star \star$ & $\star \star$ & $\star \star$ \\
\hline \multicolumn{6}{|c|}{ Intercropping x Fertilization Schemes } \\
\hline F-test & ns & ns & ns & ns & ns \\
\hline $\mathrm{CV}_{\mathrm{b}}(\%)$ & 8.34 & 3.08 & 1.54 & 14.91 & 6.51 \\
\hline
\end{tabular}

Likewise, the different fertilization schemes significantly influenced the production of vegetative tillers and plant height especially those applied with nitrogen fertilizers with or without application of chicken dung. On the contrary, plants applied with $2 t$ ha ${ }^{-1}$ chicken dung and the unfertilized ones had fewer tillers and were shorter than the $\mathrm{N}$ fertilized plants. According to Liu et al (2011), the application of nitrogen enhances the production of tillers in plants as it increases the cytokinin content within tiller nodes and enhances the germination of the tiller primordium. On the other hand, the significant increase in plant height can be attributed to the high amounts of nitrogen applied which is essential in the formation of chlorophyll (Mas 2013) to effect more production of photosynthates needed for growth.

No interaction effect between intercropping and fertilization schemes was observed implying that the said treatments acted independently and did not affect the aforementioned agronomic parameters. 
Adlay (Coix lacryma-jobi L.) and Napier grass intercropping \& fertilization

\section{Yield and Yield Components of Adlay}

Table 3 shows no significant effect of intercropping schemes on the number of tillers per hill, panicle length and number of filled grains except unfilled grains. This indicates that the napier intercrop had no adverse effect on the said parameters. However, higher number of unfilled grains were noted in adlay and napier at 1:1 ratio than the rest of the treatments. The greater number of unfilled grains per panicle of adlay intercropped with napier at 1:1 row ratio suggests that the more crowded the area, the more number of unfilled grains per panicle have developed. Triburcio (2015) reported comparable number of productive tillers among cultivars tested while Aradilla (2018) mentioned no significant differences in panicle length of six adlay cultivars grown under adverse conditions in Bukidnon.

Table 3. Productive and non-productive tillers, panicle length and filled and unfilled grains of adlay as affected by intercropping and fertilization schemes

\begin{tabular}{|c|c|c|c|c|c|}
\hline Treatments & $\begin{array}{l}\text { Productive } \\
\text { Tillers }\end{array}$ & $\begin{array}{l}\text { Non- } \\
\text { productive } \\
\text { Tillers }\end{array}$ & $\begin{array}{c}\text { Panicle } \\
\text { Length } \\
(\mathrm{cm})\end{array}$ & $\begin{array}{l}\text { Filled } \\
\text { Grains }\end{array}$ & $\begin{array}{l}\text { Unfilled } \\
\text { Grains }\end{array}$ \\
\hline \multicolumn{6}{|l|}{ Intercropping Scheme } \\
\hline $\mathrm{C}_{1}=$ Monocrop Adlay & 16.8 & 1.2 & 44.0 & 114.6 & $30.4^{\mathrm{b}}$ \\
\hline $\begin{array}{c}\mathrm{C}_{2}=\text { Adlay and Napier } \\
\text { at } 1: 1 \text { ratio }\end{array}$ & 16.2 & 1.4 & 43.2 & 116.4 & $36.3^{\mathrm{a}}$ \\
\hline $\begin{array}{c}\mathrm{C}_{3}=\text { Adlay and Napier } \\
\text { at 2:1 ratio }\end{array}$ & 16.2 & 1.2 & 42.6 & 103.2 & $29.9^{b}$ \\
\hline F-test & ns & ns & ns & ns & $\star \star$ \\
\hline $\mathrm{CV}_{\mathrm{a}}(\%)$ & 9.21 & 35.71 & 9.49 & 20.57 & 14.27 \\
\hline \multicolumn{6}{|l|}{ Fertilization Scheme } \\
\hline $\mathrm{F}_{0}=$ Unfertilized & $13.3^{c}$ & $0.9^{b c}$ & $39.1^{\mathrm{b}}$ & 104.3 & 32.5 \\
\hline $\mathrm{F}_{1}=120 \mathrm{~kg} \mathrm{ha}^{-1} \mathrm{~N}$ & $20.3^{a}$ & $2.3^{\mathrm{a}}$ & $51.0^{\mathrm{a}}$ & 116.5 & 37.1 \\
\hline $\begin{aligned} \mathrm{F}_{2}= & 60 \mathrm{~kg} \mathrm{ha}^{-1} \mathrm{~N}+1 \mathrm{t} \mathrm{ha}^{-1} \\
& \text { chicken dung }\end{aligned}$ & $18.1^{\mathrm{ab}}$ & $1.5^{\mathrm{ab}}$ & $43.0^{\mathrm{b}}$ & 111.4 & 30.4 \\
\hline $\begin{aligned} \mathrm{F}_{3}= & 30 \mathrm{~kg} \mathrm{ha} \mathrm{k}^{-1} \mathrm{~N}+1.5 \mathrm{tha}^{-1} \\
& \text { chicken dung }\end{aligned}$ & $17.0^{\mathrm{b}}$ & $1.0^{\mathrm{bc}}$ & $41.9^{b}$ & 100.7 & 29.7 \\
\hline $\mathrm{F}_{4}=2 \mathrm{t} \mathrm{ha} \mathrm{a}^{-1}$ chicken dung & $13.4^{\mathrm{c}}$ & $0.7^{c}$ & $41.3^{b}$ & 123.9 & 31.4 \\
\hline F-test & ** & ** & $\star \star$ & ns & ns \\
\hline \multicolumn{6}{|c|}{ Intercropping x Fertilization Schemes } \\
\hline F-test & ns & ns & ns & ns & ns \\
\hline $\mathrm{CV}_{\mathrm{b}}(\%)$ & 11.74 & 17.50 & 8.98 & 19.37 & 21.75 \\
\hline
\end{tabular}

On the contrary, the fertilization scheme significantly affected the development of productive and non-productive tillers and panicle length. Plots applied with $120 \mathrm{~kg} \mathrm{ha}^{-1} \mathrm{~N}$ inorganic fertilizer produced the highest number of productive and non-productive tillers and longest panicle compared to the other treatments. But the unfertilized plants and those applied solely with chicken dung had the least tillers and shortest panicles. This indicates that tiller production and panicle length can be enhanced by nitrogen fertilizer application. The findings corroborated the 
observation of Salvador (2016) that the number of productive tillers of adlay increased with application of fertilizer. Perlas and Batanes (2014) also reported that the panicle length of fertilized adlay was $84 \%$ longer than the unfertilized plants.

Results also showed that the fertilization schemes did not significantly influence the number of filled and unfilled grains per panicle which ranged from 101 to 124 and 30 to 37 pieces per panicle, respectively. The application of $2 \mathrm{t} \mathrm{ha} \mathrm{h}^{-1}$ chicken dung and $120 \mathrm{~kg} \mathrm{ha}^{-1} \mathrm{~N}$ resulted in slightly more filled and unfilled grains, respectively, compared to the other treatments. In contrast, Torred (2017) reported significant influence of fertilization on the number of grains per panicle. Mendoza et al (2015) obtained 14 unfilled grains per panicle out of the 201 to 285 filled grains per panicle of adlay.

As indicated in Table 4, the intercropping scheme did not influence the grain moisture content, weight of 1000 seeds, herbage yield and grain yield. Such results indicate that the napier intercrop did not adversely affect the said parameters. Omblero (2012) recorded no variation in moisture content but observed significant differences in herbage among adlay varieties tested. Torred (2017) found no significant difference among adlay varieties in their weight of 1000 seeds.

Table 4. Moisture content of grains at harvest, weight of 1000 seeds, herbage yield and grain yield of adlay as affected by intercropping and fertilization schemes

\begin{tabular}{|c|c|c|c|c|}
\hline \multirow{2}{*}{ Treatments } & \multirow{2}{*}{$\begin{array}{c}\text { Moisture } \\
\text { Content (\%) at } \\
\text { Harvest }\end{array}$} & \multirow{2}{*}{$\begin{array}{l}\text { Weight }(\mathrm{g}) \text { of } \\
1000 \text { seeds }\end{array}$} & \multicolumn{2}{|c|}{ Yield $\left(\mathrm{t} \mathrm{ha}^{-1}\right)$} \\
\hline & & & Herbage & Grain \\
\hline \multicolumn{5}{|l|}{ Intercropping Scheme } \\
\hline $\mathrm{C}_{1}=$ Monocrop Adlay & 16.4 & 90.2 & 26.610 & 1.509 \\
\hline $\begin{array}{c}\mathrm{C}_{2}=\text { Adlay and Napier } \\
\text { at 1:1 ratio }\end{array}$ & 16.4 & 92.7 & 25.470 & 1.513 \\
\hline $\begin{array}{c}\mathrm{C}_{3}=\text { Adlay and Napier } \\
\text { at 2:1 ratio }\end{array}$ & 16.8 & 90.0 & 26.980 & 1.351 \\
\hline F-test & ns & $\mathrm{ns}$ & ns & ns \\
\hline $\mathrm{CV}_{\mathrm{a}}(\%)$ & 5.23 & 12.21 & 10.17 & 20.28 \\
\hline \multicolumn{5}{|l|}{ Fertilization Scheme } \\
\hline $\mathrm{F}_{0}=$ Unfertilized & 17.4 & 80.8 & $23.367^{b}$ & $0.938^{b}$ \\
\hline $\mathrm{F}_{1}=120 \mathrm{~kg} \mathrm{ha}^{-1} \mathrm{~N}$ & 16.0 & 93.8 & $25.933^{\mathrm{ab}}$ & $1.909^{a}$ \\
\hline $\begin{array}{c}\mathrm{F}_{2}=\underset{\text { dung }}{60 \mathrm{~kg} \mathrm{ha}^{-1} \mathrm{~N}+1 \mathrm{tha}^{-1} \text { chicken }} \\
\end{array}$ & 16.0 & 96.6 & $28.433^{a b}$ & $1.664^{\mathrm{a}}$ \\
\hline $\begin{aligned} \mathrm{F}_{3}= & 30 \mathrm{~kg} \mathrm{ha} \mathrm{-}^{-1} \mathrm{~N}+1.5 \mathrm{t} \mathrm{ha} \mathrm{-}^{-1} \\
& \text { chicken dung }\end{aligned}$ & 16.2 & 96.0 & $30.133^{a}$ & $1.657^{\mathrm{a}}$ \\
\hline $\mathrm{F}_{4}=2 \mathrm{t} \mathrm{ha} \mathrm{P}^{-1}$ chicken dung & 17.0 & 87.5 & $23.900^{b}$ & $1.119^{\mathrm{b}}$ \\
\hline F-test & * & * & * & $\star \star$ \\
\hline \multicolumn{5}{|l|}{ Intercropping x Fertilization Schemes } \\
\hline F-test & ns & ns & ns & ns \\
\hline $\mathrm{CV}_{\mathrm{b}}(\%)$ & 7.91 & 14.94 & 6.34 & 27.77 \\
\hline
\end{tabular}


Adlay (Coix lacryma-jobi L.) and Napier grass intercropping \& fertilization

Among fertilization schemes, the results revealed a significant influence on the moisture content, weight of 1000 seeds, herbage yield and grain yield. However, when tested using Tukey's test to determine their differences, no significant differences existed on the moisture content and weight of 1000 seeds. This could be attributed to the conservative nature of Tukey's test. Torred (2017) reported a significant difference in seed weight between fertilized and unfertilized adlay plants.

Results showed that the application of $25 \%$ nitrogenous inorganic fertilizer and $1.5 \mathrm{t} \mathrm{ha}^{-1}$ chicken dung produced significantly heavier herbage yield $\left(30.133 \mathrm{t} \mathrm{ha}^{-1}\right)$ comparable to $1 / 2$ of $\mathrm{N} \mathrm{ha}^{-1}$ and $1 \mathrm{t} \mathrm{ha}^{-1}$ of chicken dung $\left(28.433 \mathrm{tha}^{-1}\right)$ and the full recommended rate of $\mathrm{N}\left(25.933 \mathrm{tha}^{-1}\right)$. Lowest herbage yield was observed from plants applied with $2 \mathrm{t} \mathrm{ha} \mathrm{a}^{-1}$ of chicken dung $\left(23.900 \mathrm{t} \mathrm{ha}^{-1}\right)$ which was at par with unfertilized plants $\left(23.367 \mathrm{t} \mathrm{ha}^{-1}\right)$. The results indicated that the inherent nitrogen content of the soil was insufficient such that addition of inorganic nitrogen source and chicken dung significantly enhanced adlay herbage production. Mas (2013) stated that nitrogen is a component of chlorophyll such that more photosynthates will be allocated for herbage production.

Plants applied with inorganic fertilizer either solely or in combination with chicken dung produced significantly heavier grains than the control plants and those applied with $2 \mathrm{t} \mathrm{ha} \mathrm{a}^{-1}$ chicken dung. The findings implied that $2 \mathrm{t} \mathrm{ha} \mathrm{a}^{-1}$ chicken dung was not enough to supply the nutrient needs of the plants. The result conforms to the findings of Salvador (2016) and Torred (2017) that inorganic fertilization resulted in higher yield than organic fertilization. Perlas and Batanes (2014), on the other hand, recorded heaviest grains in plants fertilized with $50 \%$ inorganic and $50 \%$ organic fertilizers.

Although the fertilization scheme significantly affected the above-mentioned parameters, these did not result in significant interaction with the intercropping scheme indicating the independent effect of fertilization on said parameters.

\section{Yield and Yield Components of Napier}

Statistical analysis showed no significant influence of intercropping scheme on the number of tillers and herbage yield of napier as an intercrop to adlay (Table 5). This indicates that the effect of adlay on said parameters is the same in each intercropping scheme. However, such results are inconclusive as the error df was not adequate for a valid test of significance.

The fertilization scheme also had no significant influence on the number of tillers per hill and herbage yield of napier at first harvest but had significant effect at $2^{\text {nd }}$ harvest. The unfertilized napier and those with $2 \mathrm{t} \mathrm{ha}^{-1}$ chicken dung significantly produced more tillers per hill and heavier herbage yield compared to the other treatments due to lesser shading. However, tiller number and herbage yield were much lower than that of monoculture napier indicating the effect of adlay shading on napier. The shaded napier plants in between rows of adlay with inorganic fertilizer treatments either applied solely or in combination with chicken dung did not survive until the $3^{\text {rd }}$ harvest. According to Antony (2016), for every 25 percent increase in shade level, there is 10 percent reduction in tiller number that developed in hybrid napier while Francis (2004) noted napier as a full sunlight species that can still produce under partial shade but does not withstand complete shade under a dense tree canopy. 
No interaction effect was noted on said parameters showing that the independent variables acted independently in this aspect.

Table 5. Tillers per hill and herbage yield of napier grass as influenced by intercropping and fertilization schemes

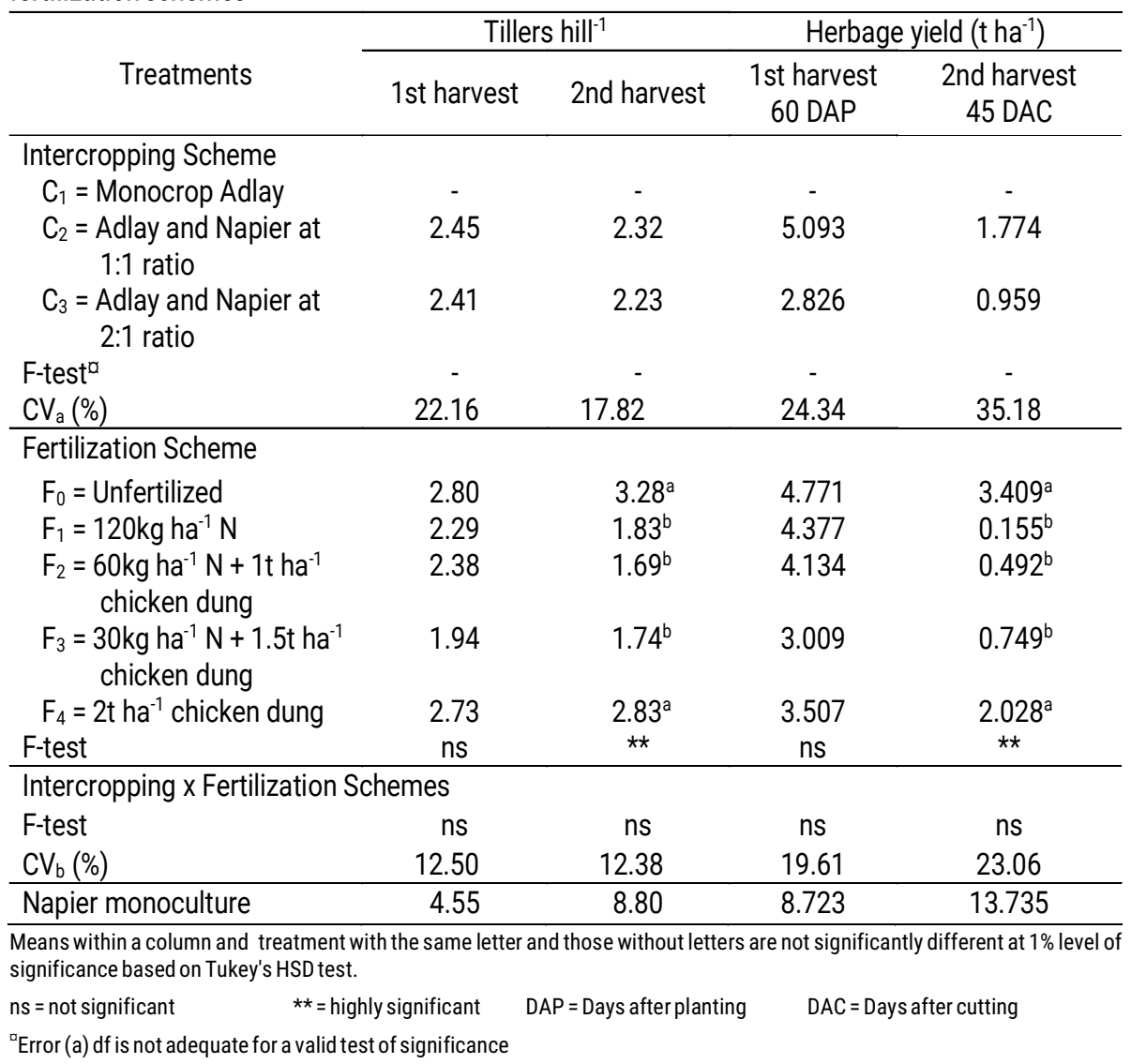

\section{Intercropping Efficiency Measures}

\section{Land Equivalent Ratio (LER)}

The land equivalent ratio (LER) did not vary significantly as influenced by intercropping scheme and its interaction with fertilization scheme (Table 6). Although not significantly different from each other, the results showed slightly higher LER was obtained by intercropping adlay with napier at 1:1 row ratio. This can be attributed to the higher population of napier intercrop in the 1:1 than in the 2:1 row ratios. According to Gliessman (2014), when LER is lower than one, the intercropping negatively affects the growth and yield of crops grown in mixtures.

The unfertilized plants had the highest LER of 1.62 which means that the other treatments need 1.62 hectares to produce the same yield of a hectare of said treatment although not significantly different with those applied with $120 \mathrm{~kg} \mathrm{ha}^{-1} \mathrm{~N}$ and $2 \mathrm{t} \mathrm{ha} \mathrm{a}^{-1}$ chicken dung with LER of 1.12 and 1.13 , respectively. Such higher 
Adlay (Coix lacryma-jobi L.) and Napier grass intercropping \& fertilization

value was attributed to higher napier yields in unfertilized treatments compared to the fertilized ones. The result suggests that intercropping adlay with napier even without fertilization is more advantageous.

Table 6. Land equivalent ratio (LER) and area time equivalent ratio (ATER) of adlay as influenced by intercropping and fertilization schemes

\begin{tabular}{|c|c|c|}
\hline Treatments & LER & ATER \\
\hline \multicolumn{3}{|l|}{ Intercropping Scheme } \\
\hline $\mathrm{C}_{1}=$ Monocrop Adlay & - & - \\
\hline $\begin{array}{c}\mathrm{C}_{2}=\text { Adlay and Napier } \\
\text { at } 1: 1 \text { ratio }\end{array}$ & 1.43 & 1.26 \\
\hline $\begin{array}{c}\mathrm{C}_{3}=\text { Adlay and Napier } \\
\text { at 2:1 ratio }\end{array}$ & 1.17 & 1.06 \\
\hline F-test ${ }^{a}$ & - & - \\
\hline $\mathrm{CV}_{\mathrm{a}}(\%)$ & 10.53 & 10.88 \\
\hline \multicolumn{3}{|l|}{ Fertilization Scheme } \\
\hline$F_{0}=$ Unfertilized & $1.62^{\mathrm{a}}$ & $1.77^{\mathrm{a}}$ \\
\hline $\mathrm{F}_{1}=120 \mathrm{~kg} \mathrm{ha}^{-1} \mathrm{~N}$ & $1.12^{\mathrm{ab}}$ & $1.03^{\mathrm{ab}}$ \\
\hline $\begin{aligned} \mathrm{F}_{2}= & 60 \mathrm{~kg} \mathrm{ha}^{-1} \mathrm{~N}+1 \mathrm{tha}^{-1} \\
& \text { chicken dung }\end{aligned}$ & $1.08^{b}$ & $0.98^{\mathrm{ab}}$ \\
\hline $\begin{aligned} \mathrm{F}_{3}= & 30 \mathrm{~kg} \mathrm{ha}^{-1} \mathrm{~N}+1.5 \mathrm{t} \mathrm{ha}{ }^{-1} \\
& \text { chicken dung }\end{aligned}$ & $1.04^{b}$ & $0.95^{\mathrm{b}}$ \\
\hline $\mathrm{F}_{4}=2 \mathrm{t} \mathrm{ha} \mathrm{-}^{-1}$ chicken dung & $1.13^{\mathrm{ab}}$ & $1.08^{a b}$ \\
\hline F-test & * & * \\
\hline \multicolumn{3}{|c|}{ Intercropping x Fertilization Schemes } \\
\hline F-test & ns & ns \\
\hline $\mathrm{CV}_{\mathrm{b}}(\%)$ & 11.57 & 14.06 \\
\hline
\end{tabular}

Significant interaction between intercropping and fertilization schemes was not noted implying their independent influence on the LER.

\section{Area Time Equivalent Ratio (ATER)}

Statistical analysis revealed that the area time equivalent ratio (ATER) did not differ significantly among intercropping schemes (Table 6). A slightly higher ATER was observed in adlay intercropped with napier at 1:1 row ratio than at 2:1 ratio due to the higher population of napier plants in the former ratio than the latter.

A significantly higher ATER value of 1.77 was obtained in the unfertilized treatment as compared to the fertilized treatments. Such a higher value can be attributed to the higher yields of napier in the unfertilized treatment due to lesser shading by the adlay plants. Unlike those of the fertilized plots, the sprouting of the napier plants after the first cutting was affected by the heavy shading caused by densier adlay growth.

Significant interaction effect between intercropping and fertilization schemes was absent which connotes their independent influence on ATER. 


\section{Cost and Return Analyses}

Table 7 reveals that adlay production was not affected by the intercropping scheme but was influenced by fertilization scheme. Interaction between intercropping and fertilization schemes was not observed in all parameters measured.

Table 7. Cost and return (PHP) of adlay production per hectare as influenced by intercropping and fertilization schemes

\begin{tabular}{|c|c|c|c|c|c|c|}
\hline $\begin{array}{l}\text { Treat } \\
\text { ments }\end{array}$ & $\begin{array}{c}\text { Adlay Grain } \\
\text { Yield } \\
\left(\mathrm{t} \mathrm{ha}^{-1}\right)\end{array}$ & $\begin{array}{l}\text { Napier } \\
\text { Fresh } \\
\text { Herbage } \\
\text { Yield } \\
\left(\mathrm{t} \mathrm{ha}^{-1}\right)\end{array}$ & $\begin{array}{c}\text { Gross } \\
\text { Return } \\
\left(\mathrm{PHP} \mathrm{ha}^{-1}\right)^{1}\end{array}$ & $\begin{array}{c}\text { Product } \\
\text { ion cost } \\
(\mathrm{PHP} \\
\left.\mathrm{ha}^{-1}\right)\end{array}$ & $\begin{array}{l}\text { Net Return } \\
\left(\mathrm{PHP} \mathrm{ha}^{-1}\right)\end{array}$ & $\begin{array}{c}\text { Return on } \\
\text { Invest } \\
\text { ment }\end{array}$ \\
\hline \multicolumn{7}{|c|}{ Intercropping Scheme } \\
\hline $\mathrm{C}_{1}$ & 1.509 & - & 75,426 & 33,449 & 41,977 & 1.21 \\
\hline $\mathrm{C}_{2}$ & 1.513 & 6.867 & 80,822 & 38,447 & 42,375 & 1.08 \\
\hline $\mathrm{C}_{3}$ & 1.351 & 3.785 & 70,366 & 32,796 & 37,570 & 1.12 \\
\hline F-test & ns & ns & ns & - & ns & ns \\
\hline $\mathrm{CV}_{\mathrm{a}}(\%)$ & 20.28 & 24.27 & 20.97 & - & 38.97 & 16.53 \\
\hline \multicolumn{7}{|c|}{ Fertilization Scheme } \\
\hline $\mathrm{F}_{0}$ & $0.938^{b}$ & $8.179^{a}$ & $51,001^{b}$ & 28,973 & $22,027^{c}$ & $0.76^{b}$ \\
\hline $\mathrm{F}_{1}$ & $1.909^{a}$ & $4.533^{b}$ & $97,734^{a}$ & 40,072 & $57,662^{\mathrm{a}}$ & $1.44^{\mathrm{a}}$ \\
\hline $\mathrm{F}_{2}$ & $1.664^{\mathrm{a}}$ & $4.626^{b}$ & $85,518^{a}$ & 37,324 & $48,194^{\mathrm{ab}}$ & $1.31^{\mathrm{ab}}$ \\
\hline $\mathrm{F}_{3}$ & $1.657^{\mathrm{a}}$ & $3.758^{b}$ & $84,719^{a}$ & 34,585 & $50,134^{\mathrm{a}}$ & $1.43^{\mathrm{a}}$ \\
\hline $\mathrm{F}_{4}$ & $1.119^{b}$ & $5.535^{b}$ & $58,718^{b}$ & 33,532 & $25,187^{\mathrm{bc}}$ & $0.74^{\mathrm{b}}$ \\
\hline F-test & $\star \star$ & $\star \star$ & $\star \star$ & - & $\star \star$ & $\star \star$ \\
\hline \multicolumn{7}{|c|}{ Intercropping x Fertilization Schemes } \\
\hline F-test & ns & ns & ns & - & ns & ns \\
\hline $\mathrm{CV}_{\mathrm{b}}(\%)$ & 27.77 & 20.18 & 27.01 & - & 50.21 & 18.39 \\
\hline
\end{tabular}

Means within a column and treatment with the same letter and those without letters are not significantly different at $5 \%$ level of significance based on Tukey's HSD test.

ns $=$ not significant $\quad * \star=$ highly significant

${ }^{1}$ Calculated by multiplying the adlay grain yield by PHP50 $\mathrm{kg}^{-1}$ and napier fresh herbage yield by PHP0.75 $\mathrm{kg}^{-1}$ as pick up price set by Phil. Carabao Center, VSU, Baybay City.

Adlay applied with $120 \mathrm{~kg} \mathrm{ha}^{-1} \mathrm{~N}$ inorganic fertilizer had the highest gross return, net return and return on investment although it was not significant to the other inorganic fertilizer treatments but was significantly different to the unfertilized and $2 \mathrm{t} \mathrm{ha} \mathrm{a}^{-1}$ chicken dung treatments. The results imply that the application of $30 \mathrm{~kg} \mathrm{ha}^{-1} \mathrm{~N}$ $+1.5 \mathrm{t} \mathrm{ha}^{-1}$ chicken dung is the most appropriate fertilization scheme for adlay production as it had a lesser production cost as compared with the treatment applied with $120 \mathrm{~kg} \mathrm{ha}^{-1} \mathrm{~N}$ which had comparable profit with an ROI of 1.43 and 1.44 , respectively. Mendoza et al (2015) reported a return on investments of 0.77 , 1.16 and 1.36 for Pulot, Gulian, and Ginampay varieties, respectively. 
Adlay (Coix lacryma-jobi L.) and Napier grass intercropping \& fertilization

\section{CONCLUSIONS}

1.The different intercropping schemes did not significantly influence the growth and yield of adlay and napier grass intercrop. However, the application of $30 \mathrm{~kg} \mathrm{ha}^{-1} \mathrm{~N}$ inorganic fertilizer $+1.5 t^{-1} a^{-1}$ chicken dung resulted in an optimum yield of $1.657 \mathrm{t} \mathrm{ha}{ }^{-1}$.

2. Intercropping efficiency with higher $\mathrm{N}$ fertilization scheme is not promising.

3. Comparable higher return on investment with those applied with $120 \mathrm{~kg} \mathrm{ha}^{-1} \mathrm{~N}$ inorganic fertilizer, yet lower production cost can be obtained from plants applied with $30 \mathrm{~kg} \mathrm{ha}^{-1} \mathrm{~N}$ inorganic fertilizer $+1.5 \mathrm{t} \mathrm{ha}^{-1}$ chicken dung.

4. Application of $30 \mathrm{~kg} \mathrm{ha}^{-1} \mathrm{~N}+1.5 \mathrm{t} \mathrm{ha}{ }^{-1}$ chicken dung is recommended especially in areas with an abundant supply of the organic fertilizer.

\section{ACKNOWLEDGMENT}

The author is grateful to the Visayas State University for the fellowship grant and the Commission on Higher Education (CHED) K-to-12 Transition Program for the dissertation grant.

\section{REFERENCES}

Antony S. 2016. Shade tolerance, nitrogen nutrition, and harvest management in hybrid napier under rainfed condition (PhD Dissertation). Kerala Agricultural University, Kerala, India

Aradilla AR. 2018. Phenology, growth and yield performance of Adlay (Coix lacryma-jobi L.) grown in adverse climatic conditions. International Journal of Research \& Review 5(3):16-24

Bandeswaran C, Radhakrishnan L \& Murugan M. 2013. Influence of various types of organic manures and different levels of nitrogen fertilization on the biomass yield and nutrient content of Napier-bajra hybrid grass. International Journal Veterinary Science 2(3):93-95

Christopher SF and Lal R. 2007. Nitrogen management affects carbon sequestration in North American cropland soils. Critical Reviews in Plant Sciences 26:45-64

Coles MFT. 2013. Organic fertilizer effects on the performance of three Adlai varieties (BS thesis). Central Mindanao University, Musuan, Bukidnon, Philippines

Cook BG, Pengelly BC, Brown SD, Donnelly JL, Eagles DA, Franco MA, Hanson J, Mullen BF, Partridge IJ, Peters M \& Schultze-Kraft R. 2005. Tropical Forages: an interactive selection tool. CSIRO, DPI\&F(QId), CIAT and ILRI, Brisbane, Australia

Francis JK. 2004. Pennisetum purpureum Schumacher. In Francis JK (ed) Wildland shrubs of the United States and its Territories: thamnic descriptions: volume 1 (pp830). Gen. Tech. Rep. IITF-GTR-26. USDA Forest Service, International Institute of Tropical Forestry

Gliessman SR. 2014. Agroecology: The ecology of sustainable food systems(3rd edn). CRC Press, Florida, USA 
Health Benefits Times.com. 2016. Health benefits of Job's Tears. http://www. healthbenefitstimes.com/health-benefits-of-jobs-tears/

Kafle $G$ and Balla MK. 2008. Effectiveness of root system of grasses used in soil conservation in Paundi Khola Sub Watershed of Lamjung District, Nepal. The Initiation 2(1):121-129

Landon JR. 1991. Booker tropical soil manual: A Handbook for Soil Survey and Agricultural Land Evaluation in the Tropics and Subtropics. Longman Scientific and Technical, Essex, New York

Lemus R and Lal R. 2005. Bioenergy crops and carbon sequestration. Critical Reviews in Plant Sciences 24(1):1-21

Liu Y, Ding YF, Wang QS, Meng DX \& Wang SH. 2011. Effects of nitrogen and 6benzylaminopurine on rice tiller bud growth and changes in endogenous hormones and nitrogen. Crop Science 51:786-792

Loeffler A. 2012. Research in sustainable agriculture identifies climate-smart crop at experimental plots in the Philippines. Virginia Tech Daily. https://www.vtnews.vt.edu/articles/2012/10/101912-oired-adlaigrass.html

Luceño JM. 2017. Response of six Adlay (Coix lacryma-jobi L.) varieties grown under drought conditions in Musuan, Bukidnon (BS thesis). Central Mindanao University, Musuan, Bukidnon, Philippines

Mas J. 2013. How does nitrogen help plants grow? Phoslab Testing Laboratories, Florida, USA. https://www.phoslab.com/how-does-nitrogen-help-plants-grow/

Mendoza AJA, Sabellano Jr FM, Baco LT, Nabua WC \& Pantallano ES. 2015. Varietal performance of Adlai (Coix lacryma-jobi L.). NMSCST Research Journal 3(1):139-147

Mercado AR Jr, Lasco RD \& Reyes MR. 2016. How Filipino farmers cope with climate change through conservation agriculture with trees. In Sajise PE, Cadiz MCH \& Bantayan RB (eds) Learning and Coping with Change: Case Stories of Climate Change Adaptation in Southeast Asia (pp201-221). World Agroforestry

Mostales JS and Aradilla AR . 2016. Field performance of six Adlay (Coix lacrymajobi, L.) cultivars under off-season planting in Musuan, Bukidnon (BS thesis). Central Mindanao University, Musuan, Bukidnon, Philippines

Omblero JB. 2012. Wet season adaptability trial of three Adlai (Coix lacryma-jobi L.) varieties in CMU, Musuan, Bukidnon (BS thesis). Central Mindanao University, Musuan, Bukidnon, Philippines

Perlas FB and Batanes JL. 2014. Nutrient management for adlay (Coix lacryma-jobi L.). Philippine Journal of Crop Science 38(Supplement 1):31

Rahman M. 2014. Carbon and nitrogen dynamics and carbon sequestration in soils under different residue management. The Agriculturists 12(2):48-55

Salvador RC Sr. 2016. Influence of seed quality and fertilizer on the field performance of three adlay (Coix lacryma-jobi L.) varieties (PhD dissertation). Central Mindanao University, Musuan, Bukidnon, Philippines

Sivakumar T, Sundaram SM, Sankaran VM \& Rajkumar JSI. 2014. Sequestering of atmospheric carbon through fodder cultivation - A measure for mitigating global warming. In Sandhu PS \& Rahman A (eds) Proceedings of the International Conference on Food, Agriculture and Biology, Kuala Lumpur, Malaysia, 11-12 June 2014

Torred MB. 2017. Formulation and utilization of liquid biofertilizers and their effect on the growth and yield performance of adlay (Coix lacryma-jobi L.) (PhD dissertation). Central Mindanao University, Musuan, Bukidnon, Philippines 
Adlay (Coix lacryma-jobi L.) and Napier grass intercropping \& fertilization

Triburcio JIL. 2015. Field performance of six Adlay (Coix lacryma-jobi L.) varieties under Musuan Condition (BS thesis). Central Mindanao University, Musuan, Bukidnon, Philippines

Zhao C, Liu B, Piao S, Wang X, Lobell DB, Huang Y, Huang M, Yao Y, Bassu S, Ciais P, Durand JL, Elliott J, Ewert F, Janssens IA, Li T, Lin E, Liu Q, Martre P, Müller C, Peng S, Peñuelas J, Ruane AC, Wallach D, Wang T, Wu D, Liu Z, Zhu Y, Zhu Z, \& Asseng S. 2017. Temperature increase reduces global yields of major crops in four independent estimates. Proceedings of the National Academy of Sciences of the United States of America 114(35):9326-9331 